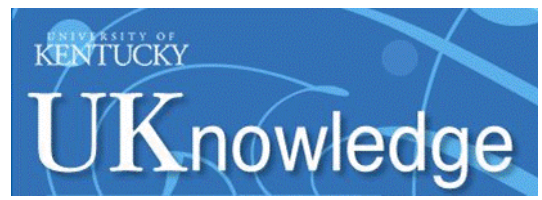

University of Kentucky

UKnowledge

\title{
Prevalence and Prognostic Features of ECG Abnormalities in Acute Stroke: Findings From the SIREN Study Among Africans
}

\author{
Abiodun M. Adeoye \\ University of Ibadan, Nigeria \\ Okechukwu S. Ogah \\ University of Ibadan, Nigeria \\ Bruce Ovbiagele \\ Medical University of South Carolina \\ Rufus Akinyemi \\ Federal Medical Centre, Nigeria \\ Vincent Shidali

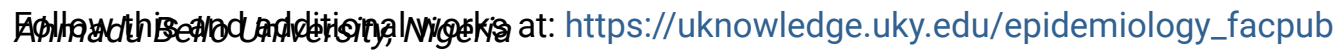 \\ Part of the African Studies Commons, Cardiology Commons, and the Epidemiology Commons \\ Bightextick to poreaditiendpackfform in a new tab to let us know how this document benefits you.
}

\section{Repository Citation}

Adeoye, Abiodun M.; Ogah, Okechukwu S.; Ovbiagele, Bruce; Akinyemi, Rufus; Shidali, Vincent; Agyekum, Francis; Aje, Akinyemi; Adebayo, Oladimeji; Akinyemi, Joshua O.; Kolo, Philip; Appiah, Lambert Tetteh; Iheonye, Henry; Kelechukwu, Uwanuruochi; Ganiyu, Amusa; Olunuga, Taiwo O.; Akpa, Onoja; Olagoke, Ojo Olakanmi; Sarfo, Fred Stephen; Wahab, Kolawole; Olowookere, Samuel; Fakunle, Adekunle; Akpalu, Albert; Adebayo, Philip B.; Nkromah, Kwadwo; Yaria, Joseph; Ibinaiye, Philip; Ogbole, Godwin; Olumayowa, Aridegbe; Lakoh, Sulaiman; Calys-Tagoe, Benedict; and Arnett, Donna K., "Prevalence and Prognostic Features of ECG Abnormalities in Acute Stroke: Findings From the SIREN Study Among Africans" (2017). Epidemiology and Environmental Health Faculty Publications. 44.

https://uknowledge.uky.edu/epidemiology_facpub/44

This Article is brought to you for free and open access by the Epidemiology and Environmental Health at UKnowledge. It has been accepted for inclusion in Epidemiology and Environmental Health Faculty Publications by an authorized administrator of UKnowledge. For more information, please contact UKnowledge@lsv.uky.edu. 


\title{
Prevalence and Prognostic Features of ECG Abnormalities in Acute Stroke: Findings From the SIREN Study Among Africans
}

\author{
Digital Object Identifier (DOI) \\ https://doi.org/10.1016/j.gheart.2017.01.002
}

\section{Notes/Citation Information}

Published in Global Heart, v. 12, issue 2, p. 99-105.

(C) 2017 World Heart Federation (Geneva). Published by Elsevier Ltd. All rights reserved.

This manuscript version is made available under the CC-BY-NC-ND 4.0 license

https://creativecommons.org/licenses/by-nc-nd/4.0/.

The document available for download is the authors' post-peer-review final draft of the article. Its title is "Prevalence and Prognostic features of Electrocardiographic Abnormalities in Acute Stroke among Africans: Findings from SIREN."

Due to the large number of authors, only the first 30 and the authors affiliated with the University of Kentucky are listed in the author section above. For the complete list of authors, please download this article or visit: https://doi.org/10.1016/j.gheart.2017.01.002

\section{Authors}

Abiodun M. Adeoye, Okechukwu S. Ogah, Bruce Ovbiagele, Rufus Akinyemi, Vincent Shidali, Francis Agyekum, Akinyemi Aje, Oladimeji Adebayo, Joshua O. Akinyemi, Philip Kolo, Lambert Tetteh Appiah, Henry Iheonye, Uwanuruochi Kelechukwu, Amusa Ganiyu, Taiwo O. Olunuga, Onoja Akpa, Ojo Olakanmi Olagoke, Fred Stephen Sarfo, Kolawole Wahab, Samuel Olowookere, Adekunle Fakunle, Albert Akpalu, Philip B. Adebayo, Kwadwo Nkromah, Joseph Yaria, Philip Ibinaiye, Godwin Ogbole, Aridegbe Olumayowa, Sulaiman Lakoh, Benedict Calys-Tagoe, and Donna K. Arnett 


\title{
Prevalence and Prognostic features of Electrocardiographic Abnormalities in Acute Stroke among Africans: Findings from SIREN
}

\section{A full list of authors and affiliations appears at the end of the article.}

\begin{abstract}
Background-Africa has a growing burden of stroke with associated high morbidity and a 3year fatality rate of $84 \%$. Cardiac disease contributes to stroke occurrence and outcomes, but the precise relationship of abnormalities as noted on a cheap and widely available test, the electrocardiogram (ECG), and acute stroke outcomes has not been previously characterized in Africans. We assessed the prevalence and prognoses of various ECG abnormalities among African acute stroke patients encountered in a multisite, cross-national epidemiologic study.
\end{abstract}

Methods-We included 890 patients from Nigeria and Ghana with acute stroke who had 12-lead ECG recording within first 24 hours of admission and stroke classified based on brain CT scan or MRI. Stroke severity at baseline was assessed using the Stroke levity scale (SLS), while onemonth outcome was assessed using the modified Rankin scale (mRS).

Results-Patients mean age was $58.4( \pm 13.4)$ years, 490 were male $(55 \%)$ and $400(45 \%)$ females, $65.5 \%$ had ischemic stroke, and $85.4 \%$ had at least one ECG abnormality. Women were significantly more likely to have atrial fibrillation, or left ventricular hypertrophy (LVH) with or without strain pattern. Compared to ischemic stroke patients, hemorrhagic stroke patients were less likely to have atrial fibrillation ( $1.0 \%$ vs. $6.7 \%, \mathrm{p}=0.002)$, but more likely to have LVH (64.4\% vs. $51.4 \%, \mathrm{p}=0.004)$. Odds of severe disability or death at one month was higher with severe stroke (AOR: 2.25; 95\% CI :1.44-3.50), or atrial enlargement (AOR: 1.45; CI:1.04-2.02).

Conclusions-About four in five acute stroke patients in this African cohort had evidence of a baseline ECG abnormality, but presence of any atrial enlargement was the only independent ECG predictor of death or disability.

\section{INTRODUCTION}

Stroke is a common neurologic condition in all regions of the world. Of the 14.1 million people who died of cardiovascular diseases (CVD) in 2012 in the world, stroke accounted for 6.7 million deaths. (1) Many people who suffer acute stroke have underlying CVD such as hypertension, atrial fibrillation, and ischaemic heart disease. (2) These underlying CVD

\footnotetext{
*Corresponding Author: Mayowa O. Owolabi, MBBS, MSc, DM, FMCP, Department of Medicine, University College Hospital, Ibadan, Nigeria, West Africa., Phone : + 234802077 5595, mayowaowolabi@yahoo.com.

Publisher's Disclaimer: This is a PDF file of an unedited manuscript that has been accepted for publication. As a service to our customers we are providing this early version of the manuscript. The manuscript will undergo copyediting, typesetting, and review of the resulting proof before it is published in its final form. Please note that during the production process errors may be discovered which could affect the content, and all legal disclaimers that apply to the journal pertain.
} 
are associated with several pre-existing electrocardiographic (ECG) anomalies such as rhythm and conduction abnormalities, and left ventricular hypertrophy (LVH) with or without ST-T changes.

However, several researchers have postulated the existence of a 'brain-heart axis' whereby structural brain lesions by themselves result in electrocardiographic changes. (3) The precise mechanism that leads to the development of these ECG changes is still uncertain, though increasing evidence suggests that it is mainly due to autonomic nervous system dysregulation. $(3,4)$ Whereas some authors attribute these ECG changes in acute stroke to underlying CVD, others have demonstrated their presence in acute stroke patients without underlying CVD. $(5,6)$

Irrespective of preexisting cardiac diseases or not, observing an abnormal ECG in an acute stroke patients more than doubled their mortality rate at 6 months (5) and these abnormal ECG changes have not been shown to be perfect predictive tool for stroke subtypes. $(6,7)$ While cardiac arrhythmia such as atrial fibrillation, and LVH has been linked with the occurrence and prognosis of acute stroke, the prognostic value of repolarization changes commonly seen after stroke such as ST segment depression, T-wave and U-wave abnormalities still remains unclear. $(8,9)$.

Despite the common occurrence of stroke in Africa, there is sparse data on the prevalence and prognostic significance of ECG abnormalities in acute stroke in the region. In addition, there is inadequate data on the contributions of cardiac arrhythmias, conduction abnormalities, LVH, QTc prolongation and QRS prolongation on one-month case fatality in acute stroke especially in the African context. Understanding these interactions will help develop interventions to reduce the morbidity and mortality associated with acute stroke.

We investigated the prevalence of specific baseline ECG abnormalities in Africans with acute stroke and their prognostic effect on severe disability or death at one-month after stroke.

\section{METHODS}

\section{Study design}

Design of the SIREN study has been described elsewhere.(10) It is a multicenter casecontrol study involving several sites in Nigeria and Ghana, which has been running since August 2014. Ethical approval was obtained from the institutional ethical committees of all study sites and written informed consent was obtained from all subjects.

Cases included consecutively consenting adults (aged 18 years or older) with first clinical stroke within 8 days of current symptom onset, or 'last seen without deficit' with cranial CT or MRI scan performed to confirm diagnosis within 10 days of symptom onset. We excluded those with stroke mimics, primary subarachnoid hemorrhage and previous strokes that were not radiologically ascertained. Stroke severity was assessed at baseline using the stroke levity scale (SLS). (11) One-month outcome was assessed using the modified Rankin scale 
(mRS).(11) Other clinical and laboratory information were obtained according to the SIREN protocol. (10)

\section{Electrocardiography}

A standard (resting) 12-lead ECG was performed in each subject using a commercially available ECG machine at $25 \mathrm{~mm} / \mathrm{s}$ and $1 \mathrm{mV} / \mathrm{cm}$ calibration. All the 12-lead ECGs were obtained within 24-hours after the onset of stroke. The ECG tracings were independently analyzed by the cardiologists who were unaware of the details of the clinical status of the patients. Abnormalities obtained from the ECGs were defined according to standard criteria as shown in Table 1.(12,13) Left ventricular hypertrophy was diagnosed using the following criteria: Sokolow-Lyon voltage (sum of the amplitudes of S wave in V1 and R wave in V5 or V6 $\geq 3.5 \mathrm{mV}$ ), sex-specific Cornell voltage (sum of the amplitudes of S wave in V3 and R wave in aVL.2.0 mV in women and $.2 .8 \mathrm{mV}$ in men). Cornell's product (CP) was calculated as the product of Cornell voltage times QRS duration. Repolarization abnormalities in leads V5 and/or V6 indicated typical strain when there was down- sloping convex ST segment with an inverted asymmetrical T-wave opposite to the QRS axis. $(14,15)$ QT interval was determined using the tangent method.(16) The measured QT interval was corrected for heart rate using the Bazett's formula. Prolonged QT interval was considered present when the QTc was >450milliseconds and >440 milliseconds in females and males respectively. Presence of other ST-T changes were documented according to standard criteria.(12) ECG definitions of criteria are in Table 1.

\section{Data management and analysis}

Quantitative variables were summarized using mean (SD) for normally distributed and median for asymmetric variables. Frequency and percentage was computed for categorical variables. To investigate the statistical significance of the difference in continuous variables according to gender and stroke type, independent samples t-test was employed. For categorical variables, the Chi-square test for the comparison of proportions was employed.

Total mRS scores 0-3 and 4-6 were categorized as good and poor respectively. Association between selected demographic, clinical characteristics and ECG findings was investigated at bivariate and multivariate levels. For bivariate analysis, chi square test was used while binary logistic regression was used for multivariate. Criteria for inclusion of variables in the logistic regression model was a p-value $<0.05$ in the bivariate or previous report in literature or basic demographic factors (age and sex). Goodness of fit was assessed using the HosmerLemeshow test.

\section{RESULTS}

The 12-lead ECGs of eight hundred and ninety subjects were analyzed. There were 490 men $(55.1 \%)$ and $400(44.9 \%)$ women. The overall mean age of all patients was $58.4 \pm 13.4$ years with women showing a non-statistically significant trend towards being older $(\mathrm{p}=0.057)$. Variables with statistically significant gender difference included BMI, diastolic blood pressure, and heart rate. These are shown in table 2. Men were less likely to have atrial fibrillation. The four cases of ventricular tachycardia occurred only in women. Women also 
had non-significant longer QT intervals and were more likely to have LVH diagnosed by Cornel voltage or product criteria. Atrial enlargement was significantly more common in men. (Tables 3 and 4)

Tables 5 and 6 depict the comparison of demographic and clinical as well as ECG abnormalities according to stroke types. Subjects with hemorrhagic stroke were significantly younger (by about 7 years) than those with ischemic stroke. They also had higher blood pressures (SBP, DBP, MAP, and PP). In terms of ECG abnormalities, atrial fibrillation was significantly more common in those with ischemic stroke, while LVH was significant in hemorrhagic stroke by any of the ECG-LVH criteria. LVH with strain, QTc duration, QRS duration and axis were comparable across stroke types.

Table 6 shows the demographic and some clinical characteristics of the subjects according to one-month disability status. The presence of sinus rhythm was associated with good mRS. Severe SLS and atrial enlargement on the 12-lead ECG was associated with poor mRS.

In a multivariate logistic regression analysis (Table 7), only severe SLS and presence of atrial enlargement were the independent predictors of one-month outcome.

\section{DISCUSSION}

In this ongoing African stroke study, women with stroke appeared older than their male counterpart with higher frequencies of tachycardia, atrial fibrillation and ventricular tachycardia. Men with stroke had higher mean diastolic blood pressure. ECG LVH was more common in women and in those with hemorrhagic stroke. There was no significant difference in the occurrence of conduction abnormalities or QT abnormalities according to gender or stroke type. $(13,17)$ The pathologic mechanism by which acute stroke generates various ECG abnormalities is still not clear. However, autonomic dysregulation due to sympathetic overactivity have been proposed. Some authors have implicated insular irritation to be responsible for the abnormal cardiac function in acute stroke.(18-23) This is thought to be mediated by impaired inhibition of the sympathetic nervous system leading to increased release of cathecholamines. $(20,23)$

The management of patients with an acute stroke demands assessment of risk for morbidity and mortality, of which hypertension is major determinant. Studies have shown that elevated BP in acute stroke is associated with poor prognosis.(24) Increased blood pressure increase the risk of bleeding in thrombolytic treatment(25) and increases the bleeding tendency in hemorrhagic stroke. (26) In our study, both systolic and diastolic blood pressures were elevated. The subjects with hemorrhagic stroke had higher mean blood pressure parameter compared with ischemic stroke. This is similar to the findings by Quresh et.al. (26)

While the studies on the pathophysiology of "acute hypertensive response" in stroke have not been exhaustive, severely high blood pressure irrespective of mechanism is associated with poor outcome. (27) Whether the high blood pressure reported in the current study was "acute hypertensive response" or poorly controlled chronic blood pressure was difficult to decipher since pre morbid cardiac state was not known. The same explanation may go for high rate of abnormal ECG findings reported in our study. About four out of five stroke 
patients studied had at least one abnormal ECG finding. Irrespective of mechanism, abnormal ECG findings is associated with poor outcome.

Over $20 \%$ of our stroke subjects had prolonged QTc. This is not different in men and women and according to stroke type. Previous studies in patients with hypertensive heart diseases or diabetes mellitus have shown that QTc prolongation and QT interval dispersion are related to increased risk of all-cause and cardiovascular mortality through malignant arrhythmias. In a study, it was shown that idiopathic abnormal QTc prolongation was associated with a fivefold increase in the probability of sudden cardiac death.(28)

Except for four cases of ventricular tachycardia (all occurred in women), no case of polymorphic tachycardia especially torsade's de pointes were recorded. This is similar to previous reports.(13) However, this may not have been picked up because continuous ECG monitoring was not carried out in our subjects. Atrial fibrillation is the most common sustained cardiac arrhythmia (29) and its presence increases stroke risk by 5-folds.(30) Interestingly, the prevalence of atrial fibrillation in our study was low. This is in contrast to earlier studies that reported high prevalence of atrial fibrillation especially in ischemic stroke among non-African populations $(30,31)$. The lower prevalence of atrial fibrillation in African stroke patients may be due to their relatively younger age, or genetic influences. Certain genetic variants have been associated with occurrence of atrial fibrillation especially the familiar type.(32) Also earlier studies have shown a paradoxical relationship between established AF risk factors and AF incidence in people of African descent compared with those of European ancestry. Despite a higher prevalence of many traditional risk factors for $\mathrm{AF}$, including hypertension, diabetes mellitus, heart failure, and larger BMI in African Americans, people of European ancestry had higher incidence of atrial fibrillation.(33) These discrepancies allows for further genomic studies in atrial fibrillation among indigenous African populations which SIREN will explore.

Furthermore, in this study more than half of the patients had LVH. LVH is a well-recognized independent risk factor for hypertensive target organ damage including stroke.(34-36) and when found with stroke it doubles the risk of repeat stroke.(37). In acute stroke therefore, it may not be a new development as it takes long period of blood pressure elevation for clinical LVH to develop; more so that more than half of the stroke patients had atrial enlargement. This suggests that probably more of our subjects had preexisting cardiac anomalies. Our findings are similar to a study by Familoni et.al who found $63 \%$ preexisting cardiac disorder in stroke patients with higher prevalence of long QT interval and reported more mortality in patients with preexisting cardiac conditions.(38)

In our study atrial enlargement and severity of stroke were major predictors of one month severe disability or death. While stroke severity is a recognized predictor of stroke outcome with more severe strokes recovering more slowly, atrial enlargement may indicate preexisting cardiovascular morbidity which impairs stroke recovery at one-month. 


\section{Strengths and Limitations}

This is the largest study so far of the prognostic implication of ECG abnormalities among indigenous African stroke patients. We provided evidence that any atrial enlargement on baseline ECG is an independent predictor of one-month outcome in this population.

It is not clear if the ECG abnormalities observed in our cohort were related to the acute stroke event since we did not have access to their ECGs prior to the stroke event. Follow up ECG was also not obtained in order to document whether the abnormalities were transient.

\section{Conclusion}

Various ECG abnormalities were observed in our stroke subjects. However, only atrial enlargement was an independent ECG predictor of one month stroke outcome. We recommend baseline ECG not only as a tool for detecting cardiac abnormalities in acute stroke patients but also to prognosticate one-month outcome. We will explore this and other ECG variables further when data collection is complete in the SIREN study.

\section{Authors}

Moshood Abiodun Adeoye, FWACP ${ }^{1}$, Okechukwu S. Ogah, FWACP ${ }^{1}$, Bruce Ovbiagele, MSc, MD², Rufus Akinyemi, MD³ , Vincent Shidali, FMCP4, Francis Agyekum, FWACP ${ }^{5}$, Akinyemi Aje, FMCP ${ }^{1}$, Oladimeji Adebayo, MB; $\mathrm{BS}^{1}$, Joshua O. Akinyemi, PhD 1 , Philip Kolo, FMCP ${ }^{6}$, Lambert Tetteh Appiah, FWACP7 , Henry Iheonye, MWACP ${ }^{4}$, Uwanuruochi Kelechukwu ${ }^{8}$, Amusa Ganiyu, $\mathrm{FWACl}^{9}$, Taiwo O. Olunuga, FMCP ${ }^{3}$, Onoja Akpa, $\mathrm{PhD}^{1}$, Ojo Olakanmi Olagoke, MWACP ${ }^{1}$, Fred Stephen Sarfo, MBChB, $\mathrm{PhD}^{7}$, Kolawole Wahab, FMCP 6 , Samuel Olowookere ${ }^{6}$, Adekunle Fakunle, MPH ${ }^{1}$, Albert Akpalu, MD ${ }^{5}$, Philip B. Adebayo, FWACP ${ }^{10}$, Kwadwo Nkromah, MD ${ }^{5}$, Joseph Yaria, MB, BS ${ }^{1}$, Philip Ibinaiye, $\mathrm{FICS}^{4}$, Godwin Ogbole, FMCR ${ }^{1}$, Aridegbe Olumayowa, B. Tech ${ }^{11}$, Sulaiman Lakoh, MWACP1, Benedict Calys-Tagoe, $\mathrm{MD}^{5}$, Paul Olowoyo, FWACP ${ }^{12}$, Chukwuonye Innocent, FMCP ${ }^{8}$, Hemant K. Tiwari, $\mathrm{PhD}^{13}$, Donna Arnett, $\mathrm{PhD}^{14}$, Osaigbovo Godwin, FWACP $^{9}$, Ayotunde Bisi, MWACP ${ }^{1}$, Josephine Akpalu, FWACP ${ }^{5}$, Okeke Obiora, FWACS $^{8}$, Odo Joseph, MWACS ${ }^{1}$, Adeleye Omisore, FMCR $^{15}$, Carolyn Jenkins, $\mathrm{DrPH}^{2}$, Daniel Lackland, DrPH ${ }^{2}$, Lukman Owolabi, MBBS, Ph. ${ }^{16}$, Isah Suleiman, B.MLS ${ }^{16}$, Abdu H. Dambatta, FMCP, FWACS ${ }^{16}$, Morenikeji Komolafe, FWACP ${ }^{15}$, Andrew Bock-Oruma ${ }^{17}$, Ezinne Sylvia Melikam, $\mathrm{MSc}^{1}$, Lucius Chidiebere Imoh, FMCP ${ }^{8}$, Taofiki Sunmonu, FMCP ${ }^{18}$, Mulugeta Gebregziabher, $\mathrm{PhD}^{2}$, Oluyemisi Olabisi, MBBS ${ }^{15}$, Kevin Armstrong, BS ${ }^{2}$, Ugochukwu U. Onyeonoro, $\mathrm{FMCPH}^{8}$, Emmanuel Sanya, FWACP ${ }^{6}$, Atinuke M Agunloye, FMCR ${ }^{1}$, Luqman Ogunjimi, MWACP ${ }^{1}$, Oyedunni Arulogun, $\mathrm{PhD}^{1}$, Temitope H. Farombi, FMCP ${ }^{1}$, Olugbo Obiabo, FMCP ${ }^{17}$, Reginald Obiako, FMCP ${ }^{4}$, and Mayowa Owolabi, MSc, Dr.M1, ${ }^{1}$ on behalf of SIREN Team as part of H3Africa Consortium

\section{Affiliations}

1 University of Ibadan, Ibadan, Nigeria

${ }^{2}$ Medical University of South Carolina, South Carolina, USA 


\author{
${ }^{3}$ Federal Medical Centre, Abeokuta, Nigeria \\ ${ }^{4}$ Ahmadu Bello University, Zaria, Nigeria \\ ${ }^{5}$ University of Ghana Medical School, Accra, Ghana \\ 6University of llorin Teaching Hospital, Nigeria \\ ${ }^{7}$ Komfo Anokye Teaching Hospital, Kumasi, Ghana \\ ${ }^{8}$ Federal Medical Center, Umuahia, Abia State \\ ${ }^{9} J o s$ University Teaching Hospital Jos, Nigeria \\ ${ }^{10}$ Ladoke Akintola University of Technology, Ogbomoso, Nigeria \\ ${ }^{11}$ Sacred Heart Hospital, Abeokuta, Nigeria \\ ${ }^{12}$ Federal University Teaching Hospital, Ido-Ekiti, Nigeria \\ ${ }^{13}$ University of Alabama at Birmingham, Birmingham, USA \\ ${ }^{14}$ University of Kentucky at Lexington, USA \\ ${ }^{15}$ Obafemi Awolowo University Teaching Hospital, Ile-Ife, Nigeria \\ ${ }^{16}$ Aminu Kano Teaching Hospital, Nigeria \\ ${ }^{17}$ Delta State University Teaching Hospital, Ogara, Nigeria \\ ${ }^{18}$ Federal Medical Centre, Owo, Nigeria
}

\title{
Acknowledgments
}

Funding

This work is supported by the National Institutes of Health (NIH) and National Institute of Neurological Disorders and Stroke (NINDS) (Grant 1U54HG007479)

\section{REFERENCES}

1. World Health Organization. The 10 leading causes of death in the world, 2000 and 2012. Geneva, Switzerland: World Health Organization; 2014.

2. Wira CR 3rd, Rivers E, Martinez-Capolino C, Silver B, Iyer G, Sherwin R, et al. Cardiac complications in acute ischemic stroke. West J Emerg Med. 2011; 12(4):414-420. [PubMed: 22224130]

3. Manea MM, Comsa M, Minca A, Dragos D, Popa C. Brain-heart axis--Review Article. J Med Life. 2015; 8(3):266-271. [PubMed: 26351525]

4. Kocan MJ. The brain-heart connection: cardiac effects of acute ischemic stroke. J Cardiovasc Nurs. 1998; 13(1):57-68. [PubMed: 9785206]

5. Bozluolcay M, Ince B, Celik Y, Harmanci H, Ilerigelen B, Pelin Z. Electrocardiographic findings and prognosis in ischemic stroke. Neurology India. 2003; 51(4):500. [PubMed: 14742932]

6. Purushothaman S, Salmani D, Prarthana KG, Bandelkar SMG, Varghese S. Study of ECG changes and its relation to mortality in cases of cerebrovascular accidents. Journal of natural science, biology, and medicine. 2014; 5(2):434.

7. Takeuchi S, Nagatani K, Otani N, Wada K, Mori K. Electrocardiograph abnormalities in intracerebral hemorrhage. Journal of Clinical Neuroscience. 2015; 22(12):1959-1962. [PubMed: 26365482] 
8. Iranmanesh F. Prognostic value of electrocardiography and electroencephalography in patients with ischemic stroke. Acta Neurol Taiwan. 2008; 17(4):228-232. [PubMed: 19280865]

9. Lazar JM, Salciccioli L. Prognostic value of QT dispersion in acute stroke. Int J Cardiol. 2008 Sep 16; 129(1):1-2. Epub 2008 Jun 24. [PubMed: 18573552]

10. Akpalu A, Sarfo FS, Ovbiagele B, Akinyemi R, Gebregziabher M, Obiako R, et al. Phenotyping stroke in sub-Saharan Africa: stroke investigative research and education network (SIREN) phenomics protocol. Neuroepidemiology. 2015; 45(2):73-82. [PubMed: 26304844]

11. Owolabi MO, Platz T. Proposing the Stroke Levity Scale: a valid, reliable, simple, and time-saving measure of stroke severity. Eur J Neurol. 2008; 15(6):627-633. [PubMed: 18474078]

12. Prineas RJ, Crow RS, Zhang Z-M. The Minnesota code manual of electrocardiographic findings: Springer Science \& Business Media. 2009

13. van Bree MD, Roos YB, van der Bilt IA, Wilde AA, Sprengers ME, de Gans K, et al. Prevalence and characterization of ECG abnormalities after intracerebral hemorrhage. Neurocritical care. 2010; 12(1):50-55. [PubMed: 19813104]

14. Roman MJ, Kligfield P, Devereux RB, Niles NW, Hochreiter C, Halle A, et al. Geometric and functional correlates of electrocardiographic repolarization and voltage abnormalities in aortic regurgitation. Journal of the American College of Cardiology. 1987; 9(3):500-508. [PubMed: 3819197]

15. Okin PM, Devereux RB, Nieminen MS, Jern S, Oikarinen L, Viitasalo M, et al. Relationship of the electrocardiographic strain pattern to left ventricular structure and function in hypertensive patients: the LIFE study. Journal of the American College of Cardiology. 2001; 38(2):514-520. [PubMed: 11499746]

16. Lepeschkin E, Surawicz B. The measurement of the QT interval of the electrocardiogram. Circulation. 1952; 6(3):378-388. [PubMed: 14954534]

17. Tatschl C, Stöllberger C, Matz K, Yilmaz N, Eckhardt R, Nowotny M, et al. Insular involvement is associated with QT prolongation: ECG abnormalities in patients with acute stroke. Cerebrovascular Diseases. 2006; 21(1-2):47-53. [PubMed: 16282690]

18. Samuels MA. The brain-heart connection. Circulation. 2007; 116(1):77-84. [PubMed: 17606855]

19. Christensen H, Boysen G, Christensen A, Johannesen H. Insular lesions, ECG abnormalities, and outcome in acute stroke. Journal of Neurology, Neurosurgery \& Psychiatry. 2005; 76(2):269-271.

20. Cechetto DF. Experimental cerebral ischemic lesions and autonomic and cardiac effects in cats and rats. Stroke; a journal of cerebral circulation. 1993; 24(12 Suppl):I6-I9. discussion I10-2.

21. Colivicchi F, Bassi A, Santini M, Caltagirone C. Cardiac autonomic derangement and arrhythmias in right-sided stroke with insular involvement. Stroke. 2004; 35(9):2094-2098. [PubMed: 15272134]

22. Oppenheimer SM, Wilson JX, Guiraudon C, Cechetto DF. Insular cortex stimulation produces lethal cardiac arrhythmias: a mechanism of sudden death? Brain research. 1991; 550(1):115-121. [PubMed: 1888988]

23. Oppenheimer SM. Neurogenic cardiac effects of cerebrovascular disease. Current opinion in neurology. 1994; 7(1):20-24. [PubMed: 8173672]

24. Leonardi-Bee J, Bath PM, Phillips SJ, Sandercock PA. Blood pressure and clinical outcomes in the International Stroke Trial. Stroke; a journal of cerebral circulation. 2002; 33(5):1315-1320.

25. Ahmed N, Wahlgren N, Brainin M, Castillo J, Ford GA, Kaste M, et al. Relationship of Blood Pressure, Antihypertensive Therapy, and Outcome in Ischemic Stroke Treated With Intravenous Thrombolysis Retrospective Analysis From Safe Implementation of Thrombolysis in StrokeInternational Stroke Thrombolysis Register (SITS-ISTR). Stroke; a journal of cerebral circulation. 2009; 40(7):2442-2449.

26. Qureshi AI, Ezzeddine MA, Nasar A, Suri MFK, Kirmani JF, Hussein HM, et al. Prevalence of elevated blood pressure in 563704 adult patients with stroke presenting to the ED in the United States. The American journal of emergency medicine. 2007; 25(1):32-38. [PubMed: 17157679]

27. Qureshi AI. Acute hypertensive response in patients with stroke pathophysiology and management. Circulation. 2008; 118(2):176-187. [PubMed: 18606927]

28. Chugh SS, Reinier K, Singh T, Uy-Evanado A, Socoteanu C, Peters D, et al. Determinants of Prolonged QT Interval and Their Contribution to Sudden Death Risk in Coronary Artery Disease 
The Oregon Sudden Unexpected Death Study. Circulation. 2009; 119(5):663-670. [PubMed: 19171855]

29. Wattigney WA, Mensah GA, Croft JB. Increasing trends in hospitalization for atrial fibrillation in the United States, 1985 through 1999 implications for primary prevention. Circulation. 2003; 108(6):711-716. [PubMed: 12885749]

30. Go AS, Hylek EM, Phillips KA, Chang Y, Henault LE, Selby JV, et al. Prevalence of diagnosed atrial fibrillation in adults: national implications for rhythm management and stroke prevention: the AnTicoagulation and Risk Factors in Atrial Fibrillation (ATRIA) Study. Jama. 2001; 285(18): 2370-2375. [PubMed: 11343485]

31. Kannel WB, Wolf PA, Benjamin EJ, Levy D. Prevalence, incidence, prognosis, and predisposing conditions for atrial fibrillation: population-based estimates. The American journal of cardiology. 1998; 82(7):2N-9N.

32. Chugh SS, Blackshear JL, Shen W-K, Hammill SC, Gersh BJ. Epidemiology and natural history of atrial fibrillation: clinical implications. Journal of the American College of Cardiology. 2001; 37(2):371-378. [PubMed: 11216949]

33. Marcus GM, Alonso A, Peralta CA, Lettre G, Vittinghoff E, Lubitz SA, et al. European ancestry as a risk factor for atrial fibrillation in African Americans. Circulation. 2010; 122(20):2009-2015. [PubMed: 21098467]

34. Wolf PA, D'Agostino RB, Belanger AJ, Kannel WB. Probability of stroke: a risk profile from the Framingham Study. Stroke; a journal of cerebral circulation. 1991; 22(3):312-318.

35. Bikkina M, Levy D, Evans JC, Larson MG, Benjamin EJ, Wolf PA, et al. Left ventricular mass and risk of stroke in an elderly cohort: the Framingham Heart Study. Jama. 1994; 272(1):33-36. [PubMed: 8007076]

36. Kannel WB. Prevalence and natural history of electrocardiographic left ventricular hypertrophy. The American journal of medicine. 1983; 75(3):4-11.

37. Pop GA, Koudstaal PJ, Meeder HJ, Algra A, van Latum JC, van Gijn J. Predictive value of clinical history and electrocardiogram in patients with transient ischemic attack or minor ischemic stroke for subsequent cardiac and cerebral ischemic events. The Dutch TIA Trial Study Group. Archives of neurology. 1994; 51(4):333-341. [PubMed: 8155010]

38. Familoni OB, Odusan O, Ogun SA. The pattern and prognostic features of QT intervals and dispersion in patients with acute ischemic stroke. Journal of the National Medical Association. 2006; 98(11):1758. [PubMed: 17128684] 


\section{Highlights}

- $\quad$ Four in five acute stroke patients in this African cohort had at least one ECG abnormality

- Atrial fibrillation was rare in the cohort occurring in $<5 \%$ overall.

- Atrial fibrillation was more common in female stroke patients.

- $\quad$ Presence of any atrial enlargement was the only independent ECG predictor of death or disability. 


\section{Table 1}

\section{Definitions of Electro-cardiographic (ECG) variables}

\begin{tabular}{|c|c|c|}
\hline \multicolumn{2}{|c|}{ ECG variables } & \multirow{2}{*}{$\begin{array}{l}\text { Definitions } \\
\begin{array}{l}\text { Absent } P \text { waves and an irregular ventricular } \\
\text { rate }\end{array}\end{array}$} \\
\hline Rhythm & $\begin{array}{l}\text { Atrial } \\
\text { Fibrillation }\end{array}$ & \\
\hline & Atrial Flutter & $\begin{array}{l}\text { Rate more than } 100 / \text { minutes and saw tooth } \\
\text { appearance of the } \mathrm{p} \text { waves }\end{array}$ \\
\hline & Sinus Rhythm & Regular p-wave with rate less between $60-100 /$ minutes \\
\hline & Sinus Bradycardia & Regular p-wave with rate less than $60 /$ minutes \\
\hline & Sinus Tachycardia & $\begin{array}{l}\text { Regular p-wave with rate more than } \\
100 / \text { minutes }\end{array}$ \\
\hline & Sinus Arrhythmia & Beat-to-beat variation in normal P-P interval \\
\hline \multirow[t]{4}{*}{$\begin{array}{l}\text { Atrial } \\
\text { enlargement }\end{array}$} & $\begin{array}{l}\text { Right atrial } \\
\text { enlargement }\end{array}$ & $\begin{array}{l}\mathrm{P} \text { wave amplitude }>2.5 \text { millimeters in lead } \\
\text { II and duration less than } 120 \text { mseconds }\end{array}$ \\
\hline & $\begin{array}{l}\text { Left atrial } \\
\text { enlargement }\end{array}$ & $\begin{array}{l}\text { Bifid } \mathrm{P} \text { wave in lead II with duration more } \\
\text { than } 120 \text { mseconds and amplitude less than > } \\
2.5 \text { millimeters in lead II }\end{array}$ \\
\hline & $\begin{array}{l}\text { Bi-atrial } \\
\text { enlargement }\end{array}$ & $\begin{array}{l}\mathrm{P} \text { wave amplitude }>2.5 \text { millimeters in lead } \\
\mathrm{II}+\text { Bifid P wave with duration more than } \\
120 \mathrm{~ms} \text { in lead II }\end{array}$ \\
\hline & Indeterminate & $\begin{array}{l}\text { None of above evidence of atrial } \\
\text { enlargement }\end{array}$ \\
\hline \multirow[t]{4}{*}{$\begin{array}{l}\text { Presence of other } \\
\text { arrhythmias }\end{array}$} & $\begin{array}{l}\text { Premature } \\
\text { ventricular } \\
\text { contraction }\end{array}$ & $\begin{array}{l}\text { QRS > 120mseconds and bizarre QRS } \\
\text { shapes }\end{array}$ \\
\hline & $\begin{array}{l}\text { Supraventricular } \\
\text { tachycardia }\end{array}$ & $\begin{array}{l}\text { Evidences of sinus tachycardia, AV Nodal } \\
\text { re-entry tachycardia(AVNRT) complexes, } \\
\text { Atrial fibrillation, Atrial flutter, Multifocal } \\
\text { atrial tachycardia, Accelerated junctional } \\
\text { tachycardia, atrial tachycardia }\end{array}$ \\
\hline & $\begin{array}{l}\text { Ventricular } \\
\text { tachycardia }\end{array}$ & $\begin{array}{l}\text { Sustained ( } 5 \text { or more consecutive beats) or } \\
\text { non-sustained tachycardia (less than } 5 \\
\text { consecutive beats) }\end{array}$ \\
\hline & None & None of above other arrthymias \\
\hline \multirow{8}{*}{$\begin{array}{l}\text { Presence of } \\
\text { conduction } \\
\text { abnormalities }\end{array}$} & $\begin{array}{l}\text { First degree AV } \\
\text { block }\end{array}$ & $\begin{array}{l}\text { PR duration }>0.20 \text { secs with normal } \mathrm{P} \text { and } \\
\text { QRS waves }\end{array}$ \\
\hline & $\begin{array}{l}\text { Second degree AV } \\
\text { block }\end{array}$ & $\begin{array}{l}\text { Progressive PR interval prolongation (> } \\
\text { 200msecs) with intermittent failed P wave } \\
\text { conduction or wide QRS(greater than } \\
\text { 120mses) with dropped QRS no prior PR } \\
\text { prolongation or evidence of advanced block }\end{array}$ \\
\hline & $\begin{array}{l}\text { Right bundle branch } \\
\text { block(RBBB) }\end{array}$ & $\begin{array}{l}\text { Deep } S \text { in lead I and V6 and tall late } R \text { wave } \\
\text { in } V_{I}\end{array}$ \\
\hline & $\begin{array}{l}\text { Left bundle branch } \\
\text { block(LBBB) }\end{array}$ & $\begin{array}{l}\text { Tall } \mathrm{R} \text { in lead } \mathrm{I} \text { and } \mathrm{V}_{6} \text { and deep } \mathrm{S} \text { wave in } \\
\text { VI }\end{array}$ \\
\hline & $\begin{array}{l}\text { Left anterior hemi- } \\
\text { block }\end{array}$ & $\begin{array}{l}\mathrm{QRS}<120 \mathrm{mseconds} \text {, left axis deviation, } \mathrm{qR} \\
\text { pattern in lead I and aVL, rS pattern in lead } \\
\text { II, III, aVF and } \mathrm{R} \text { wave peak time in aVL }\end{array}$ \\
\hline & $\begin{array}{l}\text { Left posterior } \\
\text { hemiblock }\end{array}$ & $\begin{array}{l}\text { QRS }<120 \text { mseconds, right axis deviation, } q R \\
\text { pattern in lead I and aVL, rS pattern in lead } \\
\text { II, III, aVF and } R \text { wave peak time in aVL }\end{array}$ \\
\hline & Bi-fascicular block & RBBB with left anterior hemiblock \\
\hline & Tri-fascicular block & $\begin{array}{l}\text { RBBB, left anterior hemiblock withprimary } \\
\text { AV block(or RBBB + Left anterior hemi- }\end{array}$ \\
\hline
\end{tabular}

Glob Heart. Author manuscript; available in PMC 2018 June 01. 


\begin{tabular}{|c|c|c|}
\hline \multicolumn{2}{|c|}{ ECG variables } & $\begin{array}{l}\text { Definitions } \\
\text { block+ left posterior hemiblock) }\end{array}$ \\
\hline & Complete AV block & Evidence of $\mathrm{AV}$ dissociation \\
\hline & $\begin{array}{l}\text { Indeterminate intra- } \\
\text { ventricular block }\end{array}$ & $\begin{array}{l}>110 \mathrm{mseconds} \text { with absence of RBBB } \\
\text { and LBBB }\end{array}$ \\
\hline & None & $\begin{array}{l}\text { None of the above conduction } \\
\text { abnormalities }\end{array}$ \\
\hline QT dispersion & $\mathrm{QT}_{\mathrm{C}}$ interval & $\begin{array}{l}\text { Prolonged, if duration is greater than }> \\
440 \mathrm{~ms} \text { in men or }>460 \mathrm{~ms} \text { in women }\end{array}$ \\
\hline \multirow[t]{3}{*}{$\begin{array}{l}\text { Left ventricular } \\
\text { hypertrophy }\end{array}$} & $\begin{array}{l}\text { Cornell Product } \\
\text { Criteria }\end{array}$ & $\begin{array}{l}\text { V3-S +AVL-R>2440 mms (men) } \\
\text { V3-S + AVL-R + 8mm > } 2440 \mathrm{mms} \\
\text { (women) }\end{array}$ \\
\hline & $\begin{array}{l}\text { Sokolow Lyon } \\
\text { Criteria }\end{array}$ & $\begin{array}{l}\text { V1-S + RV-5 or RV } 6 \text { if addition } \geq \\
35 \mathrm{~mm} \text { (whether male or female) there is } \\
\text { LVH }\end{array}$ \\
\hline & $\begin{array}{l}\text { Cornell voltage } \\
\text { criteria }\end{array}$ & $\begin{array}{l}\text { V3-S +AVL-R if addition } \\
\geq 20 \mathrm{~mm}(\text { Women }) \geq 28 \mathrm{~mm} \text { (men) there is } \\
\text { LVH }\end{array}$ \\
\hline
\end{tabular}




\section{Table 2}

Demographic and clinical characteristics according to gender

\begin{tabular}{lllll}
\hline Variable & $\begin{array}{l}\text { Total } \\
(\mathbf{n = 8 9 0}) \\
\text { Mean (SD) }\end{array}$ & $\begin{array}{l}\text { Males } \\
(\mathbf{n = 4 9 0}) \\
\text { Mean (SD) }\end{array}$ & Females(n=400) & p value \\
\hline Age (years) & $58.4(13.4)$ & $57.6(12.0)$ & $59.3(14.9)$ & 0.057 \\
Height $(\mathrm{m})$ & $164.7(7.8)$ & $167.7(7.2)$ & $160.9(6.8)$ & $<0.0001$ \\
Weight $(\mathrm{kg})$ & $72.4(14.3)$ & $72.7(13.6)$ & $72.1(15.1)$ & 0.678 \\
Body Mass Index $\left(\mathrm{kg} / \mathrm{m}^{2}\right)$ & $26.7(5.3)$ & $25.7(4.7)$ & $27.8(5.7)$ & $<0.0001$ \\
Systolic Blood Pressure $(\mathrm{mmHg})$ & $162.3(32.6)$ & $163.1(31.3)$ & $161.2(34.1)$ & 0.413 \\
Diastolic Blood Pressure (mmHg) & $97.2(19.2)$ & $98.9(19.5)$ & $95.1(18.6)$ & 0.004 \\
Heart Rate & $91.3(27.4)$ & $89.3(23.9)$ & $93.7(30.8)$ & 0.042 \\
Mean Arterial Pressure (mmHg) & $97.4(24.6)$ & $97.1(23.6)$ & $97.8(25.9)$ & 0.682 \\
Pulse Pressure (mmHg) & $65.0(22.4)$ & $64.1(21.7)$ & $66.2(23.3)$ & 0.205 \\
Stroke type: Ischaemic & $403(65.5)$ & $216(63.3)$ & $187(68.3)$ & \\
Haemorrhagic & $212(35.5)$ & $125(36.7)$ & $87(31.8)$ & 0.203 \\
\hline
\end{tabular}




\section{Table 3}

ECG abnormalities according to gender

\begin{tabular}{|c|c|c|c|c|}
\hline Variable & $\begin{array}{l}\text { Total }(n=890) \\
\text { frequency }(\%)\end{array}$ & $\begin{array}{l}\text { Males } \\
490(55.1 \%)\end{array}$ & $\begin{array}{l}\text { Females } \\
\mathbf{4 0 0}(44.9 \%)\end{array}$ & p value \\
\hline Atrial fibrillation & $36(4.2)$ & $12(2.5)$ & $24(6.2)$ & 0.009 \\
\hline Atrial flutter & $4(0.5)$ & $2(0.4)$ & $2(0.5)$ & 0.846 \\
\hline Other Arrhythmias & $75(8.9)$ & $38(8.2)$ & $37(9.6)$ & 0.466 \\
\hline Conduction abnormality & $106(12.7)$ & $55(12.0)$ & $51(13.5)$ & 0.539 \\
\hline Atrial enlargement & $466(55.1)$ & $273(59.1)$ & $193(50.4)$ & 0.011 \\
\hline $\mathrm{LVH}^{*}$ & $397(54.8)$ & $192(48.7)$ & $205(61.9)$ & $<0.001$ \\
\hline LVH with ST-T changes & $219(25.5)$ & $124(26.2)$ & $95(24.7)$ & 0.607 \\
\hline Prolonged $\mathrm{QT}_{\mathrm{C}}$ interval & $235(28.6)$ & $138(30.3)$ & 97 (26.5) & 0.228 \\
\hline Short $\mathrm{QT}_{\mathrm{C}}$ interval & $49(6.0)$ & $26(5.7)$ & $23(6.3)$ & 0.732 \\
\hline Any ECG abnormality & $708(85.4)$ & $381(84.5)$ & $327(86.5)$ & 0.410 \\
\hline
\end{tabular}


Table 4

Demographic and clinical characteristics according to stroke type

\begin{tabular}{lllll}
\hline Variables & $\begin{array}{l}\text { Total } \\
\text { Mean (SD) }\end{array}$ & $\begin{array}{l}\text { Ischaemic } \\
\text { Mean }(\text { SD) }\end{array}$ & $\begin{array}{l}\text { Haemorrhagic } \\
\text { Mean }(\text { SD })\end{array}$ & p value \\
\hline Age (years) & $58.3(13.2)$ & $60.7(13.1)$ & $53.7(12.2)$ & $<0.001$ \\
Height $(\mathrm{m})$ & $164.9(7.8)$ & $165.1(8.0)$ & $164.4(7.4)$ & 0.405 \\
Weight $(\mathrm{kg})$ & $73.1(14.2)$ & $73.2(14.7)$ & $72.8(13.1)$ & 0.795 \\
Body Mass Index (kg/m2) & $26.7(5.3)$ & $26.7(5.3)$ & $26.9(5.2)$ & 0.768 \\
Systolic Blood Pressure (mmHg) & $161.0(19.7)$ & $154.1(30.3)$ & $173.6(34.1)$ & $<0.001$ \\
Diastolic Blood Pressure (mmHg) & $96.8(19.7)$ & $92.6(18.4)$ & $104.5(19.8)$ & $<0.001$ \\
Heart Rate & $92.1(28.7)$ & $90.6(27.5)$ & $94.8(30.6)$ & 0.118 \\
Mean Arterial Pressure (mmHg) & $96.5(25.0)$ & $92.4(23.2)$ & $103.9(26.5)$ & $<0.001$ \\
Pulse Pressure (mmHg) & $64.2(22.9)$ & $61.5(21.5)$ & $69.1(24.6)$ & $<0.001$ \\
\hline
\end{tabular}




\section{Table 5}

ECG abnormalities according to stroke type

\begin{tabular}{lllll}
\hline Variables & Total & Ischaemic & Hemorrhagic & p value \\
\hline Atrial Fibrillation & $28(4.7)$ & $26(6.7)$ & $2(1.0)$ & 0.002 \\
Atrial Flutter & $4(0.7)$ & $4(1.0)$ & $0(0.0)$ & $0.304^{f}$ \\
Other Arrhythmias & $46(7.8)$ & $34(8.8)$ & $12(5.9)$ & 0.222 \\
Conduction abnormality & $71(12.3)$ & $47(12.4)$ & $24(12.1)$ & 0.906 \\
Atrial enlargement(any) & $340(58.0)$ & $228(58.9)$ & $112(56.3)$ & 0.541 \\
LVH $^{*}$ & $297(55.8)$ & $181(51.4)$ & $116(64.4)$ & 0.004 \\
LVH with strain & $156(26.2)$ & $94(24.0)$ & $62(30.2)$ & 0.102 \\
Prolonged QT & $171(29.6)$ & $118(31.3)$ & $53(26.4)$ & 0.216 \\
Short QT & $34(5.9)$ & $19(5.0)$ & $15(7.5)$ & 0.238 \\
QRS duration (median) & 84.0 & 84.0 & 84.0 & 0.672 \\
Median QRS Axis & 24.0 & 25.0 & 23.6 & 0.321 \\
Any ECG abnormality & $488(84.7)$ & $316(83.9)$ & $172(87.3)$ & 0.213 \\
\hline$f_{\text {Fisher's exact test }}$ & & & & \\
* & & &
\end{tabular}


Table 6

Demographic and selected clinical characteristics according to one-month disability status.

\begin{tabular}{lllll}
\hline Variables & $\begin{array}{l}\text { Good mRS } \\
(\mathbf{n = 2 5 4})\end{array}$ & $\begin{array}{l}\text { Poor mRS } \\
(\mathbf{n = 4 2 1})\end{array}$ & $\begin{array}{l}\text { Test } \\
\text { statistic }\end{array}$ & p-value \\
\hline Age (years, Mean (SD)) & $58.1(12.1)$ & $58.8(14.0)$ & 0.746 & 0.456 \\
Male gender & $161(59.2)$ & $288(54.5)$ & 1.574 & 0.21 \\
Hypertension & $255(93.8)$ & $496(93.9)$ & 0.011 & 0.916 \\
Diabetes & $106(38.9)$ & $187(35.4)$ & 0.977 & 0.323 \\
Severe SLS & $105(45.5)$ & $294(60.6)$ & 20.946 & 0.001 \\
Sinus rhythm & $239(87.9)$ & $427(80.9)$ & 6.302 & 0.012 \\
Atrial fibrillation & $8(3.1)$ & $24(4.7)$ & 1.147 & 0.284 \\
Other Arrhythmias & $24(9.2)$ & $45(9.0)$ & 0.013 & 0.961 \\
Conduction abnormality & $33(13.3)$ & $66(13.1)$ & 0.003 & 0.960 \\
Atrial enlargement & $101(38.7)$ & $243(48.8)$ & 7.046 & 0.008 \\
LVH & $138(52.9)$ & $276(53.2)$ & 0.007 & 0.936 \\
LVH with strain & $70(26.9)$ & $119(23.3)$ & 1.231 & 0.267 \\
Prolong QTC & $72(27.6)$ & $139(29.0)$ & 0.17 & 0.68 \\
Short QTC & $13(5.0)$ & $27(5.6)$ & 0.142 & 0.706 \\
Any ECG abnormality & $212(83.5)$ & $421(86.5)$ & 1.193 & 0.275 \\
\hline
\end{tabular}

mRS: modified Rankin Scale. SLS: Stroke levity scale 


\section{Table 7}

Independent factors associated with one-month disability

\begin{tabular}{lll}
\hline Variables & AOR $(\mathbf{9 5 \%}$ CI) & p-value \\
\hline Age(years) & $1.01(0.99-1.02)$ & 0.471 \\
Male gender & $1.04(0.75-1.44)$ & 0.806 \\
Hypertension & $1.24(0.62-2.48)$ & 0.549 \\
Diabetes & $0.86(0.61-1.20)$ & 0.377 \\
Stroke severity (SLS) & & \\
Mild & 1.00 & \\
Moderate & $1.17(0.73-1.87)$ & 0.506 \\
Severe & $2.25(1.44-3.50)$ & $\mathbf{0 . 0 0 1}$ \\
Atrial enlargement & $1.45(1.04-2.02)$ & $\mathbf{0 . 0 3 0}$ \\
\hline
\end{tabular}

SLS: Stroke levity scale 